\title{
From the Desk of Editor-in-Chief
}

Alhamdulillah! The Journal of Enam Medical College is being published regularly and timely in both print and electronic versions. The credit should go to teachers of Enam Medical College, contributors, reviewers, members of editorial board, office staff and Chairman and Principal of Enam Medical College for their multifarious co-operation, support and encouragement.

Improvement of the quality of a scientific journal is a continuous process. The editorial board is always working hard for this. We are committed to lift the esteem of the journal to further heights. The journal is already indexed in many indexing databases. Our next target is to get it indexed in the databases of Medline Index Medicus, PubMed and PubMed Central.

The flow of paper submission for publication in the Journal of Enam Medical College is very good. Papers are flowing in also from outside the country. This has been because of the quality of the journal and regular and timely publication.

Participation in the national and international conferences regarding publication of scientific journals would promote exchange of ideas among editors, authors, researchers, librarians and publishers of medical journals and would also expand collaboration among different countries. Editor-in-Chief of Journal of Enam Medical College participated in the Second International Congress on Medical Writing held in Ajman, United Arab Emirates on 5-7 March, 2015. Editors/representatives from different journals of the world participated in the congress. His participation in that congress has greatly acquainted the Journal of Enam Medical College and also the institution among the journal editors and research scientists attending the congress.

An earthquake of 7.8 magnitude struck central Nepal including its capital Kathmandu on April 25, 2015 causing fatalities, injuries and massive damage. We mourn the sad demise of thousands of people and express our heart-felt sympathy for the members of the bereaved families.

With all the best wishes.

Prof. Md. Aminul Haque Khan

Editor-in-Chief 